\title{
Cabeça a prêmio: tráfico, elite, Estado e violência no Brasil contemporâneo
}

\author{
Cabeça a prêmio: trafficking, elite, State and violence in contemporary Brazil
}

\author{
JULIANA OLIVEIRA LESQUIVES (1) \\ Universidade Federal da Bahia (UFBA).
}

\begin{abstract}
Resumo: O objetivo deste trabalho é analisar de que modo se configura a representação da violência no romance Cabeça a prêmio (2003), escrito por Marçal Aquino, atentando para as escolhas feitas pelo autor, ao investir na construção de uma narrativa literária sobre o tráfico de drogas, e as implicações dessa escolha para o fazer literário contemporâneo, levando em conta as reversões propostas pela narrativa no que se refere ao tratamento dado ao tema da violência.
\end{abstract}

Palavras-chave: Literatura brasileira contemporânea; Tráfico de drogas; Violência.

\begin{abstract}
The objective of this work is to analyze how the representation of violence is configured in the novel Cabeça a prêmio (2003), written by Marçal Aquino, paying attention to the choices made by the author when investing in the construction of a literary narrative about the traffic of drugs and the implications of this choice for the contemporary literature, taking into account the reversals proposed by the narrative regarding the treatment given to the theme of violence.

Keywords: Contemporary Brazilian literature; Drug trafficking; Violence.
\end{abstract}

\section{Realismo e violência em Marçal Aquino}

Em entrevista ao Epílogo, Marçal Aquino justifica seu investimento na representação dos elementos que envolvem a violência, o "submundo", a miséria em suas obras, afirmando, à semelhança de autores como Marcelino Freire e Ferréz, que sua "literatura vem da rua", influenciada sobremaneira pelas atividades desenvolvidas em sua carreira jornalística, como repórter policial. "Eu vou pra rua.
Eu posso ver um tipo de frase, ver uma situação que me dispara a vontade de fazer ficção. Então, o submundo passou pela minha experiência de repórter e veio para dentro de minha literatura por conta disso". A figura do matador de aluguel, como explica o autor, - que funciona na obra de Aquino, presença marcada em vários de seus textos, como uma chave leitura, a meu ver, para a sociedade brasileira e suas relações entre cidadãos e organização social - surge a partir da realização de uma matéria sobre matadores 
no Paraguai. A respeito da relação entre realidade e ficção, o autor sugere que a única obrigação que a literatura tem é a de ser honesta, que um escritor com muitas certezas é um farsante. Em suas palavras, a literatura é "o local da mentira" e o realismo não é necessariamente uma verdade, apenas o processo de transformação de "um fragmento de real" em uma "verdade literária".

A relação comentada por Aquino entre fato e ficção evidencia a dialética existente entre eles, indicando o caráter de retroalimentação entre realidade e representação, implicando a impossibilidade de uma representação sem evidências no real e de um real incólume às representações sociais. Desse modo, a obra de Aquino insere-se na problemática do realismo na produção literária brasileira contemporânea, ao fazer parte do fluxo de autores que escolhem essa forma de fazer literário como modo primeiro de representação, encarando os desafios que a reaparição do estilo lhes impõe.

Para Tânia Pellegrini (2007), em Realismo: postura e método, o realismo posto em prática por autores contemporâneos advém de "um olhar feroz", que se distancia do que ela chama de "olhar solidário ou apenas curioso" dos autores pioneiros do realismo no Brasil, alimentado agora pelas temáticas que envolvem o urbano, como atesta ao afirmar que:

A imaginação predominantemente citadina que alimenta a ficção de hoje reconfigura as tensões entre o "de dentro" e o "de fora", refletindose nas mediações entre a organização social urbana e a forma artística, que parece resultar, não só, mas também frise-se -, em representações explícitas, documentais, figurativas, veristas, naturalistas; realistas, enfim. Vejam-se, por exemplo, as histórias escritas por presidiários ou o registro do cotidiano violento e excludente das periferias; são testemunhos diretos, histórias de vida, de percursos e contrastes urbanos, sustentados numa espécie de imbricamento entre o etnográfico e o ficcional, parecendo ultrapassar, na sua violência paroxística, os limites da própria representação (PELLEGRINI, 2007, p. 152).

Pellegrini inclui a obra de autores como Ferréz, Aquino, Paulo Lins e Patrícia Melo, na primeira categoria definida por Ângela Maria Dias (2005, p.94), quando esta última trata da "dramatização do princípio da crueldade como perspectiva existencial e diretriz da organização formal". Essa primeira categoria diria respeito às obras que investem na "crueldade propriamente dita, dolorosa e sem escapatória". A violência, uma constante na literatura contemporânea desde seus primórdios, parece ter aflorado a partir do período da ditadura militar, em que a sociedade pode presenciar as atrocidades de que o Estado é capaz de fazer diretamente, e aparece agora em seus meandros indiretos indicando como a forma de organização que temos é capaz de violentar as pessoas, com sua configuração econômica e com suas medidas governamentais, seja dentro de uma ordem, de uma legalidade e do que se estabelece socialmente, seja nos mecanismos de uma ilegalidade, que, em grande parte da vida social, faz de modo constante parte da lógica da organização social e econômica se tornando parte das regras do jogo capitalista, suas práticas e motivações, em um estágio atual da economia global em que o acúmulo de capital e a guerra se intensificam como forças motrizes da chamada civilização, acentuando as atrocidades do processo de 
modernização que caracterizou os últimos séculos.

A literatura contemporânea brasileira, sem dúvidas, tem empregado grandes esforços na produção de prosa, em especial, na produção de contos. Rinaldo de Fernandes (2012), em artigo intitulado O conto brasileiro no século XXI, arrisca afirmar que nesse gênero literário tem acontecido a maior arremetida, expondo as inovações de linguagem e de temática. Para o autor, há algumas vertentes que podemos utilizar para analisar a produção contista contemporânea, como exposto a seguir, que nos auxiliam a pensar a problemática do regionalismo atual:

Disse, de início, que o conto tem sido o gênero de destaque em nossa literatura. Observo, nesse sentido, cinco vertentes principais do conto brasileiro do séc. XXI: 1) a da violência ou brutalidade no espaço público e urbano; 2) a das relações privadas, na família ou no trabalho, em que aparecem indivíduos com valores degradados, com perversões e não raro em situações também de extrema violência, física ou psicológica; 3) a das narrativas fantásticas, na melhor tradição do realismo fantástico hispanoamericano, às quais se podem juntar as de ficção científica e as de teor místico/ macabro; 4) a dos relatos rurais, ainda em diálogo com a tradição regionalista; 5) a das obras metaficcionais ou de inspiração pós-moderna. O que une todas essas vertentes é o olhar cruel e irônico sobre as situações configuradas. O olhar cruel sobre a existência que os nossos melhores contistas herdaram de Machado de Assis (FERNANDES, 2012, p. 175).

O relato de Fernandes se faz importante para nossa análise por arrolar o fato de que a obra de Marçal Aquino se relaciona, se não com todas, com quase todas essas delimitações de vertentes da literatura brasileira contemporânea, ainda que nosso objetivo aqui não seja classificatório. Em seu $O$ invasor (2011), aparecem a violência e a brutalidade do espaço citadino, ainda que o autor não recorra a um grande número de cenas explícitas de violência, o caos urbano e a iminência e, também, concretização do caráter violento do homem se faz em sua presença constante. Os relatos rurais e o diálogo com a tradição regionalista aparecem em Famílias terrivelmente felizes (2003), coletânea de contos escritos por Marçal Aquino, e em Cabeça a prêmio (2003) ressemantizados pelas problemáticas contemporâneas. Assim como a degradação do sujeito e as perversões perpassam toda a obra, tudo pode ser lido por um viés da metaficção que expõe as frestas da história de um país mergulhado em uma violência estrutural que nem sempre é evidenciada nessa mesma produção literária contemporânea, em favor da representação de uma violência mais evidente.

Para Mônica Miranda (2006), em trabalho sobre Famílias terrivelmente felizes (2003), "as narrativas descrevem uma sociedade que nasce da violência e se mantém pelo seu exercício, condenando as pessoas à falta de perspectiva, à desilusão e ao abandono". No relato de Miranda (2006), há algo exposto de forma um tanto despretensiosa que nos chama a atenção: trata-se da questão das "regras sociais" como formas de opressão. Analisemos:

Ideias de suicídio narradas na primeira pessoa, angústias profissionais e discriminações de raça, gênero ou deficiência física são pretexto para tratar de temas como a lógica de dominação e exclusão que perpassa a vivência de personagens pertencentes a estamentos sociais diversos como os de profissionais liberais, assalariados, 
operários e marginalizados. Aquino se aprofunda nas causas ou consequências da violência desenfreada e mostra, em sua narrativa, momentos em que regras sociais se transformam em imposições e opressões (2006, p. 26).

A análise realizada por Miranda (2006) ressalta a característica da obra de Aquino de explorar mais do que apenas as consequências geradas pela violência, como em parte significativa da produção cultural brasileira, se dedicando a suas causas, sinalizando, ainda, a transformação das regras sociais em opressões, o que nos remete a ver a violência, não como distúrbio, mas como regra. Em Aquino, essa regra não se impõe pela constância, como aparece costumeiramente em análises sobre violência em uma perspectiva mais tradicional, já que a violência não vira regra apenas porque se tornou rotineira e presente na vida das pessoas de modo mais explícito, mas, sim, porque faz parte do próprio modo de organização social moderna, no Brasil, desde a colonização, com a escravidão, base das relações de exploração, que estavam no alicerce do sistema de acumulação capitalista. Miranda (2006) não trata propriamente dessas questões, mas sua fala remete a uma análise mais complexa do que vem a ser o fenômeno da violência, que não se conforma apenas em delimitar como causa o suposto caráter violento do homem.

Outro trabalho importante sobre a escrita de Aquino, produzido por Fábio Marques Mendes (2015), que analisa também o livro de contos Famílias terrivelmente felizes (2003), constrói uma leitura fundamental para o entendimento da violência como sistema. Em Realismo e violência na literatura contemporânea, um dos objetivos de Mendes (2015) é analisar a representação do núcleo família - elemento fortemente marcado nessas narrativas, como o próprio título do livro sugere e sua confluência com o poder público, chamando atenção para a necessidade que a literatura contemporânea encontra de questionar o modelo democrático pós-ditadura militar, balizado no que ele classifica como o "funcionamento perverso do sistema social brasileiro". Conforme explana o estudioso:

A crítica ao modelo de família na literatura de Aquino diz respeito tanto à família no sentido nuclear (pai, mãe e filhos), ou seja, conformada aos ideais pequeno-burgueses e prefixada como valor e ideologia ao longo do século XIX, quanto à família no sentido positivista de unidade celular da sociedade, adequada à concepção sociológica de Émile Durkheim (2000). Tais concepções estão intrinsecamente ligadas à de Estado-nação, como apontaram os estudos de Friedrich Engels (2000). Hannah Arendt, por sua vez, também sugeriu a relação entre Estado e família ao definir a sociedade como "o conjunto de famílias economicamente organizadas de modo a constituírem o fac-símile de uma única família sobre-humana" (2010), sendo que sua forma política de organização é denominada modernamente como "nação". Assim, as narrativas de Aquino colocam em relação dialética a esfera do macropoder, o Estado brasileiro pósregime militar, e a esfera do micropoder, verificado nas representações familiares. Entretanto, é preciso adiantar aqui que as famílias dos contos de Aquino não são aquelas de tipo pequeno-burguês convencional, nem remetem ao ideal de família burguesa, mas, ao contrário, são impossibilitadas de reproduzir esses dois modelos. Isso tudo reforça a proposta do autor, qual seja, mostrar o funcionamento perverso do sistema social brasileiro por meio das pequenas narrativas (MENDES, 2015, p. 29-30). 
Mendes (2015) confere destaque à problemática da família entendendo-a como produto da concepção de família pequeno-burguesa, associada, portanto, diretamente ao modelo de organização econômica e ao Estado-nação moderno. A crítica social feita por Aquino pode ser interpretada tomando-se como eixo as fraturas nesse modelo familiar e a impossibilidade, dialeticamente instaurada, de aceitá-lo e elegê-lo como o ideal ao passo em que suas incoerências emergem na estrutura social, fundamentando, inclusive, as inúmeras violências que comumente o caracterizam. Mendes (2015) afirma que as famílias retratadas por Aquino "não são aquelas de tipo pequenoburguês convencional, nem remetem ao ideal de família burguesa". O que está em quesito, mais do que histórias de famílias esfaceladas que se distanciam do padrão imposto, é a complexidade dessa forma de relacionamento nuclear, dificuldade localizada nas consequências que o ato de inserir os indivíduos obrigatoriamente em um único modelo traz, entendendo-a como mais uma instituição que auxilia no todo da organização social, contribuindo para a perpetuação de relações violentas asseguradas pela obrigatoriedade da consanguinidade.

Essa literatura contemporânea ainda que não tenha mais uma crença num projeto redentor, não abandonou seu propósito de questionar as ordens dadas, as estruturas forçosas, a ordem estabelecida. Como discutem Schollhammer (2009) e Ginzburg (2012), a "falta" de um projeto, ou sua não materialização de modo claro, é reflexo próprio do momento atual de desenvolvimento desenfreado do sistema capitalista, do mundo caótico e desordenado, que a literatura tenta en- cenar. Daí terem surgido tantas análises literárias pautadas nas ideias de dissolução, de base pós-estruturalista, e na ideia de fragmentação dos sujeitos. Talvez se faça necessário questionar de forma mais clara e incisiva o porquê destes sujeitos estarem esfacelados, o que há de impulsionador e de paralisante nesse esfacelamento.

Marçal Aquino nasceu em Amparo, interior de São Paulo, em 1958, graduouse em Jornalismo pela PUC-Campinas, em 1983. Sua produção literária conta com romances, contos, novelas, poemas e roteiros para o cinema e para a televisão, entre os quais estão seus principais trabalhos: a novela $O$ invasor (2002), os romances Cabeça a prêmio (2003) e Eu receberia as piores notícias dos seus lindos lábios (2005) e os livros de contos Faroestes (2001) e Famílias terrivelmente felizes (2003). Sobre a classificação de seus textos no gênero policial, o escritor alega que não se incomoda, mas acha redutor, apesar de não negar o gosto pelo exercício do gênero e sua inspiração em autores como Raymond Chandler, Jim Thompson, Rubem Fonseca, Mafra Carbonieri, Ricardo Piglia, Cormac McCarthy e Scott Smith. Para o cinema, o escritor produziu roteiros juntamente com o diretor Beto Brant, com quem vem estabelecendo uma forte parceria, Os matadores (1997), Ação entre amigos (1998), O invasor (2002) e Eu receberia as piores notícias dos seus lindos lábios (2012). Firmou, também, parceria com o diretor Heitor Dhalia, nos filmes Nina (2004) e O cheiro do ralo (2007). Para a Televisão, produziu roteiros para as séries O caçador (2014), Força-tarefa (2009 - 2011) e Supermax (2016). O contato com o cinema, que o autor declara ter tido desde cedo antes mesmo do contato com a televisão, quando o acesso era 
ainda escasso, aparece vigorosamente em sua escrita, na organização do enredo, na concisão do texto, nos cortes cinematográficos das cenas.

A prosa de Aquino consegue, a partir de situações e personagens muito específicos, tratar de questões bastante complexas referentes à organização da sociedade brasileira. Seus personagens estão imersos em contextos aparentemente fora da sociedade e isolados do que seria seu funcionamento normal. No entanto, a construção da narrativa e sua movimentação confeccionam um painel social complexo em que são escancaradas as relações políticas que movimentam a dinâmica social.

No romance Cabeça a prêmio, de 2003, uns dos núcleos centrais da história é protagonizado por dois matadores de aluguel, narrado em terceira pessoa mais bem próximo da perspectiva de um deles, Brito. A dupla trabalha para fazendeiros, os irmãos Menezes, que também participam ativamente do tráfico de drogas, exportando cocaína para a Bolívia. A composição da narrativa se dá a partir de duas histórias paralelas: uma envolvendo a família Menezes e a outra sobre a história de vida de Brito, que realiza "serviços", assassinatos encomendados, para os irmãos Menezes. $\mathrm{O}$ modo de contar a história mais próximo do olhar de Brito desperta no leitor a sensação de que o trabalho realizado por ele é um trabalho como outro qualquer, impingindo a sensação de normalidade, em uma primeira leitura. Quando conhecemos as histórias das pessoas assassinadas e, principalmente, os motivos que levam os Menezes a encomendarem esses assassinatos, a teia de leituras possíveis sobre a sociedade brasileira se estabelece e a análise ganha contornos mais densos, em que se pode ler a coexistência da ilegalidade no plano do legal e da confluência de trâmites entre poder público e poder privado, ambos funcionando como peças de uma mesma engrenagem.

Sem dúvidas, Aquino lança mão dessa estratégia de utilizar histórias bem específicas a partir das quais nos é apresentada uma série de relações que caracterizam a sociedade brasileira calcada na violência, de modo a conectar a violência de contextos marginalizados à violência estrutural do funcionamento político e social do país. Desse modo, em nossa leitura, a personagem principal dos contos de Aquino é o emaranhado de relações sociais, o modo como a violência está configurada em nossa sociedade e a explicação dessa violência em suas causas e não mais focalizada em seus efeitos imediatos, sangrentos.

Partindo desse pressuposto, a análise do romance Cabeça a prêmio (2002), objeto de estudo deste trabalho, se fará levando em conta o painel construído por Aquino sobre as relações que envolvem a marginalidade, a ilegalidade, o papel do Estado e a violência como instrumento necessário a sua manutenção. O objetivo aqui é compreender como esse modo de organização social, econômica e política se utiliza tanto da ilegalidade como da legalidade para continuar funcionado. $\mathrm{O}$ "dentro" e o "fora" são vistos como dois lados de uma mesma moeda. O legal, definido pela Constituição, é facilmente "desobedecido" pela classe que dirige o Estado, uma vez que dirigi-lo implica estabelecer as regras, ainda que elas não estejam escritas, implica ainda que as regras escritas existam apenas para uma parte da população, para repressão e obediência, como será explanado a seguir. 


\section{Tráfico de drogas: o cenário e o inimigo agora são outros}

Em Cabeça a prêmio (2003), na história que apresenta tráfico de drogas, matadores de aluguel, cenários de prostituição, a violência confere uma quebra de expectativa ao promover uma mudança de contexto em relação à grande parte da produção literária e cinematográfica brasileira. O cenário do tráfico de drogas aqui não é o das grandes favelas das grandes cidades brasileiras, incrementado pela guerra das drogas estabelecida entre policiais, braço armado do Estado, e traficantes, "poder paralelo". A narrativa de Aquino opta por desviar o olhar do chamado tráfico varejista para a produção e venda de drogas a atacado.

A história se passa em uma cidade do interior e gira em torno do núcleo da família Menezes, mais especificamente dos irmãos Mirão e Abílio, fazendeiros e traficantes de cocaína, que fazem uso dos serviços de Brito e de Albano, dois matadores de aluguel, para resolver suas desavenças pessoais, financeiras e políticas.

A problemática do tráfico de drogas ilícitas, talvez o mais evidenciado quando se fala de violência nas últimas décadas, ganhou destaque tanto nas mídias jornalísticas como na produção cultural, como confirma o vasto número de obras empenhadas em retratá-lo. A expansão do número de produções sobre esse tema coaduna com o contexto contemporâneo de redemocratização em que, espantado o fantasma da ditadura militar, outras questões começaram a ser postas em pauta, coincidindo com o aumento populacional nas grandes cidades e a expansão das favelas. Mais do que isso, a maior inserção do tema se deveu a uma mudança mesmo no paradigma de atuação da esquerda brasileira que se nota no continente latino-americano desde a década de 1970, passando de uma luta contra os estados autoritários a uma luta contra as várias formas de autoritarismo, como nos esclarece Victor Hugo Adler Pereira (2007, p. 13):

Ao enfatizarem questões tradicionalmente consideradas secundárias nas lutas partidárias ou sindicais, como as desigualdades de gênero e de raça, os novos movimentos sociais trazem à cena política novos atores sociais e colocam em xeque as práticas políticas tradicionais. A produção de uma cultura vinculada à política toma direções e sentidos diferentes dos que caracterizaram uma cultura de esquerda, que teve seu apogeu no Brasil nos anos 1960, nas lutas contra a ditadura militar. Neste estudo, dou continuidade à discussão que venho realizando em minhas pesquisas, sobre os possíveis comprometimentos dessa produção cultural e das práticas em que se fundamenta com a consolidação de projetos neoliberais no Brasil a partir dos anos 1990, de políticas da "visibilidade" e da "inserção social".

Sobre essa mudança de paradigma, o autor esclarece:

Configura-se, a partir dos anos 1990, a crescente influência nos movimentos sociais de um discurso sobre a pobreza e a questão social bastante distinto daquele dominante nos anos 1960. Associa-se a esse discurso a proposta de suprir as deficiências do Estado neoliberal, que tem como meta se ausentar cada vez mais no atendimento das necessidades da população; daí a proliferação de Organizações Não Governamentais (ONGs) a partir daquela década. A atuação dessas ONGs relaciona-se diretamente à importância crescente na política brasileira 
do "jogo de identidades". A arte e a cultura exercem papel importante nos projetos socioeducativos com crianças e jovens das ONGS, declaradamente como instrumento de construção da autoestima, mas também na função de vitrine das empresas que, anunciando nos meios de comunicação o reconhecimento de sua responsabilidade social, patrocinam atividades ditas de inclusão social (PEREIRA, 2007, p. 13).

Pereira (2007) sinaliza ainda os contrastes entre as produções do período anterior e as surgidas após o golpe militar, em que predominava uma preocupação com a explicação estrutural para as mazelas sociais, de acordo com o exposto a seguir:

[...] Desse modo, enquanto na arte participativa ou engajada do Brasil nos anos de 1930 ou de 1960 predominava o enfoque do pobre ou do marginal em uma teia de relações que remetiam às mazelas de uma economia estruturada de modo injusto, apoiada num sistema político opressor, a partir dos anos de 1990 começa a surgir no país uma literatura que situa seu círculo de observação e indagação em espaços comunitários delimitados e submetidos à carência dos bens e serviços que abundam em outros espaços sociais. Esta última perspectiva sugere, muitas vezes, apenas a constatação da má distribuição dos recursos, em determinados locais quase que marcados pela maldição ou por um estigma irracional, e não a consciência quanto à natureza de um sistema em que a desigualdade é fator estrutural e, portanto, a regra. Relacionada ao relevo concedido à particularidade das experiências de sujeitos excluídos na construção de projetos políticos, surge uma produção cultural em que se busca dar vOz a essas particularidades (PEREIRA, 2007, p. 14).
Constrói-se, assim, um "rosto" para a pobreza e para a criminalidade. Essa leva de produções que pretendem dar visibilidade às pessoas marginalizadas, necessária e urgente, não se configurou sem contradições várias, como em toda representação.

Nessa teia representacional, a narrativa de Aquino elenca, complexa e paradoxalmente, além dos elementos apontados por Pereira (2007), elementos outros no tratamento do tema da violência e do tráfico de drogas no Brasil. O cenário não é mais o das grandes favelas e dos confrontos entre traficantes e a polícia, mas vai buscar o ponto inicial do trajeto da mercadoria ilícita, a gênese de sua produção, os indivíduos e as relações que dela fazem parte, bem como as instituições envolvidas. As características entre as representações dos indivíduos e das relações ora se aproximam, ora se distanciam das representações comuns de traficantes de drogas urbanos. O contraste começa pelo modo de vida dos irmãos Menezes, que são fazendeiros, ricos. A festa oferecida pelos irmãos à comitiva de um chefe do tráfico do Cartel de Cali, com o qual têm negócios, caracteriza o ambiente de riqueza. Sobre essas condições, podemos ler no romance o fragmento seguinte:

Festa chique - com bufê, garçons e músicos vindos de Porto Velho e muito barulhenta. Era uma noite chuvosa, mas isso não atrapalhava: uma imensa lona azul protegia a área onde as pessoas se aglomeravam em mesas e numa pista de dança improvisada. Fazia muito calor. As mulheres haviam caprichado nos vestidos, nos cabelos, nas joias e na maquiagem. Boa parte dos homens usava terno. Até mesmo Mirão se apertava num paletó cinza- 
rato. Ele e Abílio conversavam com o colombiano numa das mesas. O sujeito tinha a pele escura, olhos puxados e cabelos escorridos. Era imberbe. Quase um índio. Parecia inofensivo, mas sua ficha na Interpol o classificava como um assassino cruel e como um nome em ascensão no Cartel de Cali (AQUINO, 2003, p. 39-40).

A cena contrasta com o ambiente ao qual costumamos associar o tráfico, enfatizada pela mídia e associada à pobreza. A própria descrição do chefe do tráfico colombiano o classifica como aparentemente inofensivo, de um sujeito que em sua fisionomia não oferece riscos, para em seguida fazer a ressalva de que sua ficha policial o colocava como um procurado traficante cruel. Por trás da aparência civilizada, encontra-se a violência. Movimento semelhante acontece com a apresentação de Mirão e de Abílio. Os Menezes são apresentados ao leitor da seguinte forma:

O homem era Valdomiro Menezes. Mais conhecido como Mirão. Um animal de grande porte. Brito havia se encontrado com ele pela primeira vez três anos antes. Pesava mais de 150 quilos. Sujeito calmo, bonachão, quase bovino. Até que alguma coisa o tirasse do sério. Existiam duas maneiras de lidar com ele, caso estivesse enfurecido. A primeira era fugir para bem longe, mudar de nome, de país. A segunda, com uma arma na mão. De preferência, uma bazuca. Tinha um irmão, Abílio, seu oposto. Magro, tenso, uma pilha. Nervoso, destrambelhava de vez. Solteirão, diziam que era bicha. Uma vez espancou uma menina num hotel de Porto Velho. Brito estava junto, pensou em interferir. Mas, com Abílio, não valia a pena. Os irmãos Menezes. Na verdade, os dois eram terríveis quando se descontrolavam.
E isso acontecia com certa facilidade. Existira um terceiro Menezes, Nicanor, que Brito não chegou a conhecer. Já estava morto quando começou a trabalhar para Mirão e Abílio. Havia um boato, difícil de ser confirmado, de que os dois tinham tramado a morte do irmão. No começo, os Menezes eram fazendeiros e contrabandistas. Depois, aderiram ao pó e, nos últimos anos, às armas. Um império, que comandavam de uma fazenda na região de Aripuanã (AQUINO, 2003, p.36-37).

Mirão é também descrito como tranquilo apenas na aparência, extremamente violento e descontrolado, faz um tipo calmo e engraçado. Já Abílio é descrito como tenso e nervoso já em sua aparência. No entanto, o emblema da homossexualidade, que quebra o protótipo de masculinidade associado ao mundo do crime, traz uma fissura na representação. A esse respeito, o narrador faz questão de enfatizar que "na verdade, os dois eram terríveis quando se descontrolavam". A violência está incrustrada nas relações que os dois estabelecem com as pessoas e com o negócio, inclusive entre os próprios irmãos, como sugere o comentário sobre o assassinato de Nicanor, terceiro irmão, que teria sido tramado por Mirão e Abílio. Nicanor era irmão gêmeo de Abílio e não aceitava o fato de o irmão ser homossexual. Nicanor encomenda a morte de Abílio para Albano, que informa o alvo sobre as intenções do irmão de "acabar com a pouca-vergonha", se referindo à sexualidade de Abílio. Abílio oferece o triplo do valor a Albano para que ele inverta a situação e mate Nicanor.

Os traficantes aqui pertencem a outra classe social, responsáveis mesmo pela produção e distribuição da droga, atuam no atacado e não no varejo como 
os traficantes menores. Utilizam-se da violência em suas relações, mas também a terceirizam quando necessário, com o uso dos serviços dos matadores de aluguel. Não precisam enfrentar a polícia no corpo a corpo diariamente, não são estigmatizados socialmente, nem expostos na mídia como a causa central da violência urbana que precisa ser eliminada urgentemente. Compõem a classe dominante e até os serviços de violência de que se utilizam são pagos dentro de relações trabalhistas. Albano e Brito são empregados dos Menezes, assim como Dênis, o piloto que transporta a droga até a Colômbia, além de fazerem uso da "troca de favores", como fica claro na cena em que Mirão vai até o Paraguai buscar Elaine que havia fugido de casa, em transcrição a seguir:

Mirão tivera problemas para sair do Paraguai. Quando procurou por Lucas Cerqueira no hotel, o rapaz da recepção disfarçou e deu um jeito de avisar a polícia. Mirão precisou inventar uma história para explicar sua relação com o pistoleiro morto. Que não adiantou, não convenceu os policiais paraguaios. E ele teve de acionar o primeiro escalão de seus contatos, mexer os pauzinhos, como se diz, para ser liberado. Claro que ficou puto com isso. Odiava dever favores. (AQUINO, 2003, p. 149).

Os irmãos fazendeiros começaram como contrabandistas - não é dito na narrativa qual era o objeto do contrabando -, em seguida, enveredaram pelo comércio ilegal de drogas e depois pelo comércio ilegal de armas.

$\mathrm{Na}$ sociedade, de modo geral, a questão do tráfico de drogas ilícito no Brasil se tornou um instrumento de controle social da população pobre através da criminalização da pobreza. Várias ações arbitrárias executadas pelas forças policiais são vistas como necessárias pela sociedade em muito influenciada pelo alarde feito pela mídia juntamente com a demonização do traficante, estigma que se estende aos moradores de favelas de igual modo, validam a violência cometida pelo Estado, entre elas, a pena de morte ilegal através de execuções sumárias. Assim, o problema do tráfico de drogas é transformado em uma verdadeira "guerra contra as drogas", encontrando respaldo na população, no discurso religioso e no próprio sistema penal. Cria-se, desse modo, o mito do "poder paralelo", igualando forças e apagando o fato de o tráfico ser produto de um sistema, sustentado, também, por um Estado e seus interesses econômicos e de controle social, elegendo um "inimigo interno" como alvo a ser combatido e também como bode expiatório dos problemas da nação. (MORAIS, 2006). No discurso oficial, propagado pelas classes média e alta, o culpado pelos problemas do país é o pobre, negro, periférico, que, de acordo com esse pensamento, não quer contribuir para o progresso nacional e precisa, então, ser eliminado.

Esse discurso deixa de ver uma questão maior, que é o fato de o próprio Estado, lido aqui em seu caráter burguês, ajudar a sustentar o tráfico, dentro de sua característica própria de comando da legalidade, através da criação e execução das leis, que, como dito, criminalizam a pobreza, através da ilegalidade, da burla dessas leis quando lhe convém, e da criação de códigos e práticas paralelos. Como explica Morais (2006), não são muitas as regiões produtoras de maconha e cocaína, as drogas mais comuns, que para chegar até os grandes centros urbanos, "dependem de uma complexa rede de 
transporte atacadista de drogas produzidas em outros estados (caso da maconha) e em outros países (caso da cocaína)" (MORAIS, 2006, p. 118). Dessa forma, o que se tem é que:

[...] a complexidade desse processo envolve vultosos investimentos e um grau elevado de corrupção de agentes estatais que poderiam frustrar a circulação da droga. Isso envolve um nível de relacionamentos, articulações e poderes - inclusive econômicos - do qual não são dotados os agentes do tráfico das favelas, que, via de regra, se limitam ao varejo da droga. $\mathrm{O}$ comércio atacadista das drogas recebe investimentos e coordenações de membros das classes mais favorecidas, que se escondem atrás de operações financeiras e lavagem de dinheiro. A ilicitude do tráfico, se para o segmento varejista significa risco de prisão ou morte, para o segmento atacadista, representa aumento dos lucros. (BATISTA apud MORAIS, 2003, p.41).

O tráfico de drogas alimenta também o tráfico de armas, que se converte em elemento lucrativo para alguns agentes politicamente influentes, por também depender dessa rede de transporte e de trâmites ilegais licenciados por agentes do próprio Estado. Morais (2006, p. 118) explica que:

[...] da mesma forma, o armamento pesado utilizado pelos agentes do tráfico varejista demanda uma complexa rede de contrabando. Por suas semelhanças com o mercado atacadista das drogas, o tráfico de armas é dirigido e recebe investimentos de membros de classes sociais econômica e politicamente influentes. Logo, os conflitos armados do tráfico de drogas proporcionam largos lucros a grandes investidores do contrabando de armas. Também nesse mercado, em algumas circunstâncias agentes estatais - principalmente das forças armadas e polícias - "lucram" com o fornecimento clandestino de armas a agentes do tráfico de drogas. Contudo, é a indústria bélica transnacional - com destaque para a de países como EUA, Israel, Rússia, Alemanha e Suíça - a maior beneficiada com este comércio produzindo legalmente armas que são utilizadas pelos agentes do tráfico e pela polícia.

Segundo Antônio Rangel Bandeira, pesquisador do projeto de Controle de Armas da ONG Viva Rio, em depoimento à CPI das Armas, em 2011, o maior problema do Brasil quando se refere ao tráfico de armas é interno e não externo como costumam proclamar as autoridades brasileiras. De acordo com ele, 93\% do armamento ilegal do país provêm do tráfico interno e $63 \%$ dessas armas foram comercializadas legalmente antes de irem para o narcotráfico. Bandeira (2011) ainda chama a atenção para o fato de que cabe ao Exército controlar o comércio legal de armas, através do Departamento de Fiscalização de Produtos Controlados (DFPC), resquício da ditadura militar, que se tentou mudar com o Estatuto do Desarmamento, mas que não foi acatado pelos militares em conivência com os políticos. O sociólogo afirma ainda que o controle realizado pelo Exército é negligente, ao ouvir de um general que o controle de uma das maiores fabricantes de armas era feito pela própria fabricante. Para ele,

[...] isso demonstra que não há controle interno. As armas saem dos fabricantes e caem na mão do crime organizado. Quem tem que responder por isso são as autoridades brasileiras de fiscalização. Jogam essa cortina de fumaça para dizer que vem de fora. A indústria de 
armas e munição alimenta o tráfico e precisamos fiscalizar isso. Mesmo o armamento estrangeiro utiliza munição brasileira para todo tipo, inclusive os de calibre pesado. Em termos de Brasil, a média de armamento estrangeiro é de 7\% (BANDEIRA, 2011).

Além desses, aponta também colecionadores, atiradores e clubes de tiro como responsáveis por engrossarem o caldo do tráfico de armas e conluio com organizações do crime organizado, como o PCC - Primeiro Comando da Capital.

O tráfico de drogas ilícitas e de armas é resultado de um processo complexo e amplo de caráter estrutural. "Há inúmeros interesses do Estado e da classe social que o dirige na manutenção dessa atividade, especialmente se a maior parte do tráfico de drogas varejista se perpetuar ilícito e circunscrito às favelas e bairros pobres das cidades." (MORAIS, 2006, p. 118). Assim, o Estado faz uso da existência da prática ilícita da venda de drogas para dar legitimidade ao violento controle social sobre a população pobre. Morais (2006) afirma: "Estudar o Estado e suas relações com as sociedades implica, necessariamente, estudar os mais variados aspectos que envolvem o próprio funcionamento das instituições responsáveis por essa sociedade" (MORAIS, 2006, p. 120). Morais (2006) se refere, ainda, a um dos mitos criados para fundamentar essa situação do tráfico de drogas no país: trata-se do mito do poder paralelo, que incute na população a ideia de que o poder exercido pelos traficantes na favela sobre a população em decorrência da abstenção do poder público precisa de uma resposta com a presença deste último de forma mais incisiva através da ocupação das comunidades por forças policiais.
Em Cabeça a prêmio (2003), os fazendeiros que movem o tráfico se utilizam de favores no alto escalão do próprio país e em outros, Bolívia e Paraguai, fazem o transporte da mercadoria em avião próprio, com intensão de aumentar a frota, e possuem empregados e jagunços. As relações aqui seguem o modelo capitalista, além dos termos utilizados, negócios de família, liderança, chefia, escritório, o objetivo de lucro e a exploração do trabalho, como é possível apontar na cena a seguir:

Como de costume, o piloto sentou-se em sua cadeira de lona, na sombra do barracão de madeira, enquanto esperava que carregassem o avião. Fazia mais de 35 graus. Dois meninos transportavam os pacotes da caminhonete e entregavam ao homem, que os acondicionava no monomotor. Um rapaz, com o rosto cheio de espinhas, acompanhava a distância, bandoleira do fuzil atravessada no peito. [...] Um pássaro amarelo pousou no galho de uma árvore no fim da clareira. O rapaz pegou o fuzil e apontou. Daí fingiu que disparava, imitando o som do tiro. Os meninos gostaram da brincadeira; o homem, não. E bastou um olhar para que o rapaz pendurasse a arma no ombro e retornasse à posição anterior. Ele sorriu de um jeito tímido para o piloto. Vestia uma camisa surrada, bermuda jeans e estava descalço. Não devia nem saber ler, Dênis calculou (AQUINO, 2003, p. 57).

Dos quatro indivíduos que trabalhavam no carregamento da droga, dois eram crianças, como faz questão de enfatizar o autor ao chamá-los apenas de "meninos" e mostrá-los se divertindo com uma peraltice de um terceiro rapaz que faz a "segurança", armado. Sobre esse rapaz, a descrição se estende um pouco mais: a roupa gasta, os 
pés descalços e o pouco estudo. Sobre o homem, nada se sabe. São sujeitos sem rosto, sem nome, sem posses, trabalhando para o tráfico. Nesse ponto, similar aos "soldados do tráfico" urbanos, não são os chefes, não lideram o negócio, não detém os lucros. Conforme Osvaldo Coggiola, em O comércio de drogas hoje, "o grosso dos camponeses e operários 'pisadores' que se veem forçados a cultivar e processar a coca não só mantêm sua condição de superexplorados, como sofrem a renovada pressão do aparato do Estado e dos cartéis, associados em 'esquadrões da morte' e em bandos de pistoleiros do latifúndio" (p.3). O lucro do negócio permanece nas mãos do "patrão", do "chefe". A narrativa de Aquino, desse modo, expõe o estado de miséria em que vivem as pessoas que trabalham para o tráfico nesse outro cenário, da produção no interior do país, o que se assemelha com o estado de miséria em que vivem os indivíduos que cumprem função similar desse trabalho nos centros urbanos.

O tráfico funciona com feição de organização empresarial, através de acordos estabelecidos com outros grupos de traficantes, para que não haja problemas que prejudiquem os negócios. No romance de Aquino, essas informações surgem no momento em que Mirão tenta descobrir o que aconteceu com seu avião que havia sumido durante um trajeto. Sem saber que Dênis, o piloto, havia roubado o dinheiro recebido pela carga e pela venda do avião e fugido com Elaine, filha de Mirão, o fazendeiro traficante levanta as seguintes hipóteses:

$\mathrm{Na}$ época das queimadas, quando um avião sai de um ponto e não chega ao destino, todo mundo pensa logo em acidente. $\mathrm{E}$ a notícia não demora a circular. Porém não houve nenhum registro de queda de aviões - e Mirão sabia que Dênis era um piloto cuidadoso e experiente. A segunda hipótese: apreensão de carga pela polícia. Também nesse caso a notícia não demorava. E ele não recebera nenhuma informação desse tipo. Havia uma terceira possibilidade, mais remota: interceptação do avião por outra quadrilha, uma das faltas mais graves no código não-escrito dos contrabandistas e traficantes. Raras vezes acontecia. Funcionava como uma declaração de guerra - e ninguém gostava disso. Atrapalhava os negócios (AQUINO, 2003, p. 125).

Mirão estava relativamente tranquilo quanto ao relacionamento com os outros traficantes. Nesse contexto, não há uma guerra desenfreada porque ninguém quer ter prejuízo, nem chamar a atenção, diferentemente dos confrontos constantes entre traficantes e entre policiais e traficantes no tráfico varejista das grandes cidades. Ainda nesse sentido, há um distanciamento no que se refere à autoimagem que Brito, o matador de aluguel que trabalha para o tráfico internacional, e o que seriam "traficantes pequenos", "gente de segunda", instituindo um distanciamento em relação a sua condição, o que também reflete sua visão de (ex) policial sobre a população marginalizada. Analisemos:

Brito estacionou perto de um viaduto e entrou num bilhar. Um antro de itens suspeitos, dos salgadinhos sobre o balcão aos homens que jogavam nas mesas ou que assistiam às partidas sentados em cadeiras de metal. [...] Ele alternou goles de cachaça e de cerveja e observou com atenção a fauna de assemelhados ao seu redor. Gente da noite: malandros, pequenos traficantes, desocupados. Gente de segunda, de todas as idades, e cores de pele cinzenta 
prevaleciam. Caralho, o que eu estou fazendo nesta merda de lugar? Foi esse o pensamento que atingiu Brito feito um relâmpago. Ele se levantou, pagou e saiu do bilhar. Noite de cão. De cães ferozes (AQUINO, 2003, p. 144-146).

Brito é responsável por inúmeros assassinatos, executados para defender os interesses pessoais, financeiros e políticos de grandes traficantes e, em grande parte do tempo, parece não refletir muito sobre a estrutura em que se encontra ou sobre a lógica que domina as motivações para os crimes que comete. Ele não se reconhece nas pessoas do chamado submundo porque trata seu trabalho como se fosse apenas um trabalho comum, não interessando para o que servia. Sobre o personagem, o narrador comenta: "Brito era fanático por TV. Lia de modo errático (revistas e gibis, nunca livros) e não se interessava por política. Talvez não soubesse direito nem quem era o presidente da República." (AQUINO, 2003, p. 117). Em Brito, o status de emprego, a divisão do trabalho, faz com que ele pense que não tem relação direta com o tráfico em si, que apenas executa o que o chefe manda no que diz respeito aos assassinatos. Um dos poucos pontos de reflexão social de Brito se dá na seguinte passagem:

Uma vez, Brito assistiu em Ji-Paraná à pregação de um pastor, com quem Mirão tinha negócios. Era um bom orador, sabia fazer pausas dramáticas, mudava a entonação da voz para enfatizar o que dizia. Brito notou que os fiéis, um bando de caboclos e mestiços de índios, a maioria desdentada, ficaram impressionados. Numa igreja improvisada em um barracão, o pastor anunciava o caos para breve. Asneiras. Uma frase do pastor, contudo, ele preservou: a humanidade precisava de reparos. De vez em quando, Brito pensava nessa frase (AQUINO, 2003, p. 137).
Em outra cena, Brito se encontra com dois meninos em situação de rua que o assaltam, sem que o matador revide. Brito ainda pensa em reagir, mas reconhece o amadorismo dos meninos, entrega o dinheiro e vai embora. Esse ponto da narrativa mostra como o personagem se sente distante daquela realidade e sua opção por não reagir estabelece um contraponto entre os personagens: os meninos de rua são agentes da violência amadores, Brito, um profissional. Segue a cena:

Quando Brito abriu a porta do carro, os dois meninos surgiram de uma zona escura sob o viaduto. Quinze anos cada um, no máximo. Ambos negros. Enrolados em cobertores, como mendigos. Brito se encostou na lateral do carro, ficando de frente para os dois. A dor em seu estômago cessara. O bicho estava anestesiado. A grana, tio. Rápido. A mão do menino que falou surgiu empunhando uma faca comprida. A mão que Brito colocou para trás, e que poderia ter pego o revólver, voltou carregando sua carteira. Ele separou as notas, estendeu-as para os meninos. O que segurava a faca as recolheu. Dá os documentos também, anda. Brito sorriu. Pena que o bicho tivesse se acalmado. Não vou dar os documentos não. Os dois meninos se entreolharam. Não estavam preparados para aquilo. $\mathrm{O}$ menino da faca ainda tentou: Eu vou te furar. A mão de Brito já tocava a coronha do revólver desde que ele sorrira. Nenhum dos meninos havia percebido o movimento. Amadores. Vambora, Zito. Já pegamos a grana mesmo. O menino da faca viu que seu companheiro se afastava. Ele encarou Brito por um instante, xingou-o e também desapareceu sob o viaduto. Brito entrou no carro e foi para casa. (AQUINO, 2003, p. 147).

Brito não se reconhece nos traficantes menores, nem reconhece que trabalha 
para o tráfico. O serviço de Brito é para ele como um serviço cirúrgico: ele planeja e executa e a identidade da vítima não Ihe diz respeito. Nessa leitura, o tráfico ganha, ainda mais, estatuto de comércio. A narrativa de Aquino parece nos impor um questionamento: o tráfico é ilegal, nas duas situações (praticado nas favelas e praticado pela elite), mas, na realidade, a quem o Estado, através da polícia e do sistema jurídico, persegue e executa? Sobre essa relação entre legalidade e ilegalidade, Immanuel Wallerstein (1991), em Tempo espaço geopolítico episódico, afirma:

\begin{abstract}
A história dos povos e das instituições mostra que a noção de legalidade é intrínseca a toda organização social, mas a condição de legalidade ou de ilegalidade de qualquer ação é mutável no tempo e no espaço. Isso ocorre porque as normas jurídicas, as circunstâncias diplomáticas, os dispositivos técnicos mobilizados geram concepções de tempo e espaço distintas. Nessas circunstâncias, as definições de tempo e espaço são de curta-duração, e os eventos a elas relacionados são provenientes do contexto imediato [...]. (WALLERSTEIN, 1991, apud MOTA, 2014).
\end{abstract}

Sobre essa condição pode-se pensar a ilegalidade do Estado como circunstancial, dadas como exemplo as mudanças que são feitas nas leis, em tempos de crise, que prejudicam a população, ao transformarem o que era considerado anteriormente legal em ilegal e vice-versa. A ilegalidade do estado confere o poder autolegitimatório para que ele próprio aja de forma ilegal, considerando seu caráter de responsabilidade pelo regimento da existência humana. Assim, ilegalidade e lei do mais forte se tornam pares.
Em Cabeça a prêmio (2003), o trabalho de matador, de Brito e Albano, não serve apenas para ajudar a gerenciar o tráfico, mas também a vida dos grandes traficantes e manter sua condição social. Brito parece ter consciência apenas quanto à "pouca relevância" de sua existência dentro desse sistema, se auto intitulando como um homem provisório.

A figura do matador, assim, caminha na ilegalidade para o propósito de manter as coisas funcionando dentro de uma determinada ordem. Legalidade e ilegalidade se aproximam em sua manifestação, a diferença incide na autorização dada pelo Estado para que se possa agir. Brito, assim como Albano, é ex-policial, expulso da corporação por extorsão. A figura ambígua de Brito, como ex-agente legal atuando em nome do Estado e da segurança pública e, atualmente, como pistoleiro a serviço do tráfico, nos oferta uma questão sobre o funcionamento da organização social brasileira e suas raízes profundas. Essa dualidade é explorada na narrativa de modo bastante contundente. Odete e Rosamaria, mulheres com as quais Brito e Albano se envolvem durante um dos trabalhos realizados em busca de mais uma vítima a ser assassinada, acham que os dois pistoleiros são, na verdade, policiais encarregados de investigar um assalto a um Banco, ocorrido na cidade na semana anterior à estadia deles. Rosamaria sugere que os dois homens sejam policiais ou bandidos, por andarem armados.

O perfil de Brito é traçado como o de um homem de poucas palavras, que fala o essencial da forma mais simples e que não gosta de gente, informação reiterada por várias vezes durante a narrativa, ele não gostava dos "assemelhados". A única vez 
que Brito se apaixonara fora por Marlene, uma ex-prostituta, dona de um prostíbulo em São Paulo. A história entre os dois é malsucedida por conta das diferenças nas projeções de vida feitas por cada um. O narrador enfatiza: "Brito e Marlene. Por que não deram certo? Tinham as mesmas fomes, pelo menos no começo". Marlene queria ter filhos e Brito não comungava com essa ideia, o matador não queria ter filhos por conta do trabalho que realizava. O relacionamento descambou de vez quando Marlene descobriu que Brito é um matador de aluguel. Até então, ela, assim como Odete e Rosamaria, também achava que ele era policial por andar armado, até que Marlene se depara com as evidências de que Brito era matador de aluguel, a partir de uma foto do homem que deveria ser assassinado por ele.

Marlene descobre a "profissão" de Brito, juntando os fatos e decide pôr fim no relacionamento. Depois disso, os dois não se encontraram mais. O rompimento do único relacionamento de Brito que "dera certo" confirma o "caráter provisório" atribuído a ele pelo narrador, característica maior de homens como ele, Albano e Lucas Cerqueira, outro pistoleiro que também aparece no romance de Aquino. Lucas, diferentemente de Brito e Albano, não trabalha exclusivamente para os Menezes. Lucas é autônomo, como descreve seu perfil:

Lucas Cerqueira. Albano estava falando de uma lenda do mundo da pistolagem. Lucas era um alagoano que trabalhava de forma independente, um especialista em casos difíceis. Nunca recusava encomendas - tinha em seu currículo dois vereadores e pelo menos um prefeito e um juiz. Sempre agia sozinho e cobrava caro por seus serviços (AQUINO, 2003, p. 97).
O histórico de Lucas denota as relações estabelecidas entre a legalidade e a ilegalidade, operadas pelo tráfico. Era mais experiente e autônomo e como descreve seu perfil, o preço de seus serviços era alto. $\mathrm{O}$ crime se mantém eliminando agentes que não são interessantes para os negócios, nunca agentes diretos, tais como policiais, mas agentes que movem a organização e a administração do poder público. Os indivíduos, por esse lado, agem desafiando o Estado quando nele encontram entraves. Mas, é importante frisar que, na narrativa de Aquino, essa relação entre crime e Estado é bastante controversa, uma vez que também são feitos usos de serviços ilegais de agentes desse mesmo Estado para que vantagens sejam angariadas. No episódio em que Mirão ordena que seus pistoleiros encontrem o piloto Dênis, que havia roubado sua carga e seu avião e fugido com Elaine, a filha do chefe, a informação do paradeiro dos dois é conseguida através de um conchavo com um funcionário do Ministério:

Estavam no restaurante de um hotel, em companhia do advogado de Mirão, à espera do contato do Ministério. O advogado riu do comentário e disse que Albano devia ter morrido numa fogueira em alguma encarnação passada. Brito não gostava do bando de burocratas engravatados que comia nas mesas ao seu redor, mas adorava Brasília. Em sua opinião, a cidade parecia existir sem levar em conta as pessoas. Uma cidade em que a presença humana tinha jeito de provisória. O contato do advogado juntou-se a eles na mesa. [...] O sujeito escreveu [o endereço do paradeiro de Denis] num guardanapo e o entregou ao advogado, que o repassou a Albano. Ele leu e perguntou: Onde fica isso? O sujeito respondeu olhando para o advogado. Interior de São Paulo. [...] Se o piloto testemunhar, vai foder com 
tudo. Na manhã daquele dia, a prisão preventiva de Mirão e Abílio havia sido decretada. Ambos estavam foragidos tinham removido Abílio às pressas do hospital. Albano soprou o café, bebeu e então sorriu. Ele não vai testemunhar (AQUINO, 2003, p. 165).

As instituições nas narrativas de Aquino agem, ainda que na ilegalidade, como motores da sustentação do crime. Polícia, Ministérios, Igreja, Governo, envolvem-se com o crime como agentes diretos e/ou facilitadores. Esse indicativo de leitura nos é fornecido pelo perfil dos assassinados: empresários adversários políticos indesejados, sindicalistas incômodos e pessoas outras aleatórias ou das quais não sabemos a história. Nos são dados, pelos menos, três perfis de vítimas importantes para compreender o modo como Aquino representa a violência no país. O primeiro deles é o perfil de Carlito Seixas, radialista, que estava criando transtornos para a campanha de um prefeito local, ao divulgar à população, por meio de um programa em sua rádio, improbidades cometidas pelo prefeito, amigo dos Menezes. A mando de Mirão, Brito assassina Carlito, seu primeiro trabalho como matador. Sobre o perfil de Carlito e a problemática envolvendo o prefeito, o leitor é informado de que:

Do meio-dia a uma, horário em que comandava um programa de variedades ao vivo, os telefones da rádio ficaram congestionados pelas ligações de ouvintes. O povo, Carlito pensou, porra, era o povo manifestando apoio à cruzada que ele promovia contra o prefeito da cidade. Carlito fora informado de que o político planejava candidatar-se a deputado e iniciara uma agressiva campanha de denúncias pelo rádio. Era um sucesso. Depois do programa, como fazia todos os dias desde que enviuvara, foi até a Cantina Gênova, um reduto de oposição ao prefeito. Vários clientes o cumprimentaram, elogiando sua campanha. Aquele era um momento glorioso em sua vida. [...] Almoçou com o vereador que o municiava de informações sobre o prefeito. Recebeu mais material para denúncias, documentos estarrecedores. la botar pra quebrar. E melhor ainda: o almoço ficou por conta do vereador (AQUINO, 2003, p. 19).

A motivação para o assassinato de Carlito aparece de modo bastante claro, assim como a satisfação do prefeito com o corrido, como é demonstrado na cena em que o prefeito aparece comemorando o fato, juntamente com seus aliados políticos.

O prefeito passou pelo velório de Carlito Seixas no final da tarde de quartafeira. Postou-se ao lado do caixão e baixou a cabeça, como se orasse. O rosto do radialista estava sereno, intacto. Parecia dormir. A informação que o prefeito recebera falava de dois tiros. Ele cumprimentou os parentes e conhecidos, um por um, olhando firme nos olhos. Havia um zunzum, o prefeito sabia, conversas pela metade. Ele permanecia tranquilo: Carlito tinha um monte de inimigos. Do velório, o prefeito e seus assessores seguiram direto para a chácara de um aliado político, nos arredores da cidade. Da rodovia, já era possível sentir o cheiro da carne. Ele gostou daquilo, era fã de um bom churrasco. Os homens e mulheres que estavam na chácara beberam até o fim da noite. Comemoravam. Houve um tumulto alegre no momento em que alguém propôs que o prefeito desse o nome de Carlito Seixas a uma rua da cidade. Ele ergueu seu copo. Boa ideia. Vou mandar pesquisar se existe algum beco sem nome por aí. Todos riram muito (AQUINO, 2003, p. 28).

A violência na perspectiva de Aquino move as relações políticas no país, 
garantindo postos de poder na política, ao eliminar os obstáculos indesejados, que, nesse acaso, diz respeito ao fato de permitir que a população tenha conhecimento acerca das ações ilegais cometidas por seus representantes políticos. Essa violência, em Cabeça a prêmio (2003), referente às relações políticas reaparece no caso do sindicalista, Josué, assassinado pela dupla de pistoleiros, por ter feito denúncias sobre a exploração de trabalho escravo. A violência perpassa a relação política e trabalhista:

O sindicalista que Albano e Brito procuravam se chamava Josué. Fizera tanto barulho com denúncias sobre trabalho escravo no Acre que precisou sumir do Rio Branco por uns tempos. Já havia escapado de dois atentados e decidira se esconder num lugarejo perto de Elvora, na fronteira com o Peru. Albano e Brito tiveram muito trabalho para descobrir seu paradeiro. Demoraram quase duas semanas. Josué nunca ficou sabendo que os dois pistoleiros estiveram tão próximos dele. E muito menos que um telefonema de Albano, comunicando a Mirão que fizera contato visual com o alvo, acabou por salvar sua vida. Mas isso foi depois. O sindicalista Josué, naquele momento, teve sua vida poupada. Involuntariamente. Ganhou uma sobrevida de mais três meses, depois que outro pistoleiro o matou (AQUINO, 2003, p. 133).

Aquino, ainda, sagazmente assemelha a violência praticada pelos pistoleiros e sua familiaridade com os homicídios à frieza, talvez revertida em forma de apoio e ideologia, da elite, e também crueldade e violência, ao nos apresentar o pensamento do matador Albano sobre o episódio do assassinato do índio Galdino Jesus dos Santos, em Brasília, no ano de 1997, cometido por quatro homens e um menor de classe alta, quando da estadia de Galdino na cidade para levar ao Congresso Nacional reivindicações de seu grupo indígena: "Albano ficara fascinado com a notícia de que um grupo de adolescentes queimara um índio vivo em Brasília. Os dois haviam passado pela cidade quase um mês depois e o assunto ainda dominava a maioria das conversas. Albano comentou que iria pôr fogo em alguém qualquer hora, bastava aparecer uma oportunidade." (AQUINO, 2003, p. 163).

Aquino avança na representação ao desenhar o cenário do crime como um cenário em que o protagonista é um integrante da elite brasileira, fazendeiro, dono de terras. E, mais ainda, ao colocálo como sujeito que move relações com agentes públicos, e dessa forma o crime se sustenta. Assim, a violência nos textos de Aquino é fruto de uma teia de relações que mantém os interesses de quem tem lucro com o tráfico e com o contrabando, quem está na cena principal são os grandes traficantes, contrabandistas, agentes do governo, por analogia, os donos de lojas e fábricas de armas, a elite.

\section{Referências}

AQUINO, Marçal. Cabeça a prêmio. São Paulo: Cosac \& Naify, 2003.

AQUINO, Marçal. Entrevista concedida à

Revista O Grito, em 2009. Disponível em: http://www.revistaogrito.com/page/author/luiza. Acesso em: jan. 2018.

AQUINO, Marçal. Entrevista concedida ao Cinema de Buteco, em 2014. Disponível em: https://www.cinemadebuteco.com.br/destaques/ entrevista-marcal-aquino/. Acesso em: jan. 2018. https://doi.org/10.17771/pucrio.acad.2818

AQUINO, Marçal. Entrevista concedida ao Rascunho, julho de 2014, ed. 171, coluna Inquérito. Disponível em: http://rascunho.com. br/sempre-o-incomodo. Acesso em: jan. 2018. 
AQUINO, Marçal. Eu receberia as piores notícias dos seus lindos lábios. São Paulo: Companhia das Letras, 2005. https://doi. org/10.11606/issn.1981-7169.crioula.2018.143306

AQUINO, Marçal. Famílias terrivelmente felizes. São Paulo: Cosac \& Naify, 2003. https:// doi.org/10.7476/9788579837005

AQUINO, Marçal. O Invasor. São Paulo: Companhia das Letras, 2011.

DIAS, Ângela Maria. As cenas da crueldade: ficção brasileira contemporânea e experiência urbana. Estudos de literatura brasileira contemporânea, Brasília, n. 26, p.87-96, jul./dez. 2005. https://doi.org/10.1590/s231640182012000100006

FERNANDES, Rinaldo de. O conto brasileiro do século XXI. Revista Graphos, v. 14, n. 1, p. 173-188, 2012.

GINZBURG, Jaime. Crítica em tempos de violência. São Paulo: Editora da Universidade de São Paulo, 2012. https://doi. org/10.29381/0103-8559/2019290134-42

MENDES, Fábio Marques. Realismo e violência na literatura brasileira contemporânea: os contos de famílias terrivelmente felizes, de Marçal Aquino. São Paulo: Cultura Acadêmica, 2015. https://doi.org/10.7476/ 9788579837005

MIRANDA, Mônica. Os jogos narrativos e a violência nas obras de Bonassi, Aquino, Moreira, Haneke e Von Trier. Dissertação (Mestrado em Letras) - Programa de PósGraduação em Letras, Universidade Federal de Minas Gerais, Belo Horizonte, 2006. https://doi.org/10.24873/j.rpemd.2018.11.236

MORAIS, Marcelo Navarro de. Uma análise da relação entre o Estado e o tráfico de drogas: o mito do "poder paralelo". Ciências Sociais em perspectiva, Cascavel, v. 5, n. 8, p.117-136, 1 o sem. 2006.

MOTA, José Cicero da. Contrabandos e descaminhos nas fronteiras de Mato Grosso: um olhar da imprensa (1952-1979). 2014. 114f. Dissertação (Mestrado em História) Universidade Federal de Mato Grosso, Instituto de Ciências Humanas e Sociais, Cuiabá, 2014 https://doi.org/10.5327/z2176947820150053
OS MATADORES. Brasil, 1997. Direção de Beto Brant. Roteiro: Beto Brant, Marçal Aquino, Fernando Bonassi e Victor Navas. Montagem: Willen Dias.

PELLEGRINI, Tânia. Realismo: postura e método. Letras de Hoje, v. 42, n. 4, p.137-155, dez. 2007.

PEREIRA, Victor Hugo Adler. Documentos da pobreza, desigualdade ou exclusão social. Estudos de literatura Brasileira Contemporânea, Brasília, n. 30, p.11-26, jul./dez. 2007.

SCHOLLHAMMER, Karl Erik. Ficção brasileira contemporânea. Rio de Janeiro: Civilização Brasileira, 2009.

Recebido em: 10/01/2019

Aceito em: 04/04/2019

Publicado em: 15/06/2019

\begin{abstract}
Autora:
Juliana Oliveira LesQuives

Possui Graduação em Licenciatura em Letras Vernáculas pela Universidade Federal da Bahia - UFBA (2009), Mestrado em Literatura e Cultura pelo Programa de Pós-Graduação em Literatura e Cultura da Universidade Federal da Bahia - UFBA (2012) e Doutorado em Literatura e Cultura pelo Programa de Pós-Graduação em Literatura e Cultura da Universidade Federal da Bahia - UFBA (2018). Tem atuação na área de Letras no ensino de Língua Portuguesa na Educação Básica e de Literatura Brasileira e de Leitura e Produção Textual na Educação Superior Desenvolve pesquisa sobre as representações da violência na produção literária e cinematográfica brasileira contemporânea. Contato principal para correspondência:

Orcid: http://orcid.org/0000-0003-4537-4877

E-mail: julilesquives@hotmail.com
\end{abstract}

